NBER WORKING PAPERS SERIES

FISCAL FEDERALISM IN EUROPE:

LESSONS FROM THE UNITED STATES EXPERIENCE

Robert P. Inman

Daniel L. Rubinfeld

Working Paper No. 3941

\author{
NATIONAL BUREAU OF ECONOMIC RESEARCH \\ 1050 Massachusetts Avenue \\ Cambridge, MA 02138 \\ December 1991
}

Professor of Finance and Economics, University of Pennsylvania and Research Associate, NBER, and Professor of Law and Economics, University of California, Berkeley, respectively. This paper is part of NBER's research program in Taxation. Any opinions expressed are those of the authors and not those of the National Bureau of Economic Research. 
NBER Working Paper \#3941

December 1991

\section{FISCAL FEDERALISM IN EUROPE: \\ LESSONS FROM THE UNITED STATES EXPERIENCE}

\section{ABSTRACT}

The existing political and legal institutions of fiscal policy-making are under challenge. As the United States and the eastern European and Soviet states experiment with policy decentralization, the states of western Europe are looking to a more centralized policy structure via the E.E.C.. This paper seeks to raise issues of importance to all such reform efforts--notably, the need to consider, and balance, the inefficiencies of fiscal policy decentralization (spillovers and wasteful fiscal competition) against the inefficiencies of fiscal policy centralization (policy cycles and localized "pork barrel" spending and taxes). The need to develop new fiscal policy institutions emphasizing voluntary agreements and responsive "agenda-setters" is stressed.

Robert $P$. Inman Department of Finance and Economics The Wharton School of Management University of Pennsylvania Philadelphia, PA 19104 and NBER
Daniel L. Rubinfeld School of Law and Department of Economics University of California Berkeley, CA 94720 


\section{FISCAL FEDERALISM IN EUROPE:}

\section{Lessons from the United States Experience'}

$$
\text { by }
$$

\section{Robert P. Inman and Daniel L. Rubinfeld ${ }^{2}$}

In democratic and totalitarian regimes alike, the existing political and legal institutions of economic policy-making are under challenge. The wisdom of centralized fiscal regimes is now being questioned: quietly under the banner of the "new federalism" in the United States and vocally, if not violently, through the secessionist movements of eastern Europe and the Soviet states. As these nations experiment with decentralized fiscal institutions, the countries of western Europe are now looking to the potential of a more centralized economic order within the new European Economic Community. This paper seeks to raise issues of importance to all such reform efforts and, within that context, to offer some cautionary advise for the design of E.E.C. fiscal institutions based upon the recent American experience with centralized fiscal policy-making.

\section{The Role for Central Govemment Fiscal Policies in Economic Unions}

The European Community's progress towards an economic and monetary union

1 The authors wish to thank Allesandra Casella and Barry Eichengreen for helpful comments and discussions.

2 The authors are Professor of Finance and Economics, University of Pennsylvania and Research Associate of the NBER and Professor of Law and Economics, University of California at Berkeley, respectively. Professor Rubinfeld gratefully acknowledges the support of the Center for Real Estate and Urban Economics at the University of Califomia, Berkeley. 
based upon a common currency will create new demands for the design of fiscal policy. ${ }^{3}$ Perhaps most importantly, with a common currency and thus a common monetary policy, member states will no longer be able to influence their local economies through exchange rate or monetary policies when state-specific economic shocks occur. ${ }^{4}$ State-specific fiscal policies stand as an altemative. Three questions arise: 1) Can member state fiscal policies be effective in offsetting local economic shocks in an integrated economic union; 2) If effective, are such policies likely to be optimally managed at the state level; and 3) If ineffective or non-optimal, what central govemment policies might be then preferred? The recent United States experience is instructive on each point.

Can member state fiscal policies be effective? In open, integrated economies, deficit financed demand creation may be of only limited usefulness to small member states. First, the demand stimulus of deficit financing is dissipated through import demands from other union states. Gramlich (1987) has shown that the effectiveness of deficit policies in the smallest U.S. states is significantly import constrained, though larger states may be able to use own deficits to affect state employment prospects. Second, in member states the use of such deficits to combat local shocks may be significantly limited by what the capital markets will allow. While deficits may be

\footnotetext{
3 See Eichengreen (1990).
}

4 There is growing evidence of the economic importance of state-specific economic shocks to the short-run and long-run prospects of states and regions in integrated economic unions; see Bemard and Durlauf (1991) for a study of OECD countries many of which are in the E.E.C. and Brown, Coulson, and Engle (1990) for a study of U.S. states. Mernber states which manage these shocks well are likely to enjoy higher long-run growth. 
beneficial to the local economy during downtums and while member states may promise to repay those deficits with surpluses during the upswing, such promises are difficult to enforce. The U.S. capital market has appeared reluctant to accept a state's promise of a balanced budget over a business cycle; such promises lack credibility when temporary economic downtums are not easily distinguished from long-run structural declines. When "good" deficits cannot be distinguished from "bad", the only credible local government promise may be a balanced budget in each fiscal year. The stringent U.S. state budgets for the recessionary 1992 fiscal year--balanced through major tax increases and deep spending cuts-offer evidence on the point. ${ }^{s}$

Even.if member state deficit policies are economically feasible, their management may be non-optimal. In interdependent economic unions, the benefits from local demand creation through deficit financing may spillover to other member states via import expansion, while the interest costs of deficits remain with the borrowing state. The result will be an under-provision of expansionary fiscal policies by member states, using the arguments of Hart (1982). ${ }^{6}$ Central government fiscal policies stand as the policy alternative.

5 A few states have responded to this lack of capital market credits during recessionary periods by creating their own "rainy day" funds during good years and depleting those funds during economic downturns. In effect, they are borrowing from their own taxpayers. Unfortunately, these funds were insufficient to prevent the harsh fiscal choices of this current recession, suggesting that taxpayers--particularly if they are mobile--may be reluctant lenders too.

- The simulations of Gramlich (1987, Table 1) also show that as benefit spillovers increase with greater import substitution and as the local costs of borrowing rise, U.S. states have significantly reduced incentives to use local fiscal policies to manage economic downtums. 
The United States policy response to the problems of localized economic shocks has been the implementation of an experience-rated, unemployment insurance program for member states. States are required to make contributions to a central insurance fund based upon their employment histories and are allowed to withdraw from the fund for benefit payments during recessionary periods. Experience-rating and centrally constrained benefits help to control problems of moral hazard while experience-rating and mandatory participation eliminate the problem of adverse selection. Uncorrelated, local economic shocks are well managed by such an insurance mechanism. ${ }^{7}$

Central government fiscal policies will also be needed to finance (and perhaps provide) those public goods with significant externalities across member states. Environmental policies, collective military defenses, and redistributive concerns by citizens for residents of member states other than their own are possible examples. Voluntary agreements between member states for the provision of these goods are possible, but at a minimum, a central government administrative structure will be needed to enforce the arrangements. While the new analysis of the voluntary provision of public goods suggests that such agreements may well provide some positive levels of the public good, efficient provision should not be expected. ${ }^{8}$ Central govemment public goods provision--not just administration--may be desirable; NATO is has recently been shown

7 Common economic shocks are not, however. Fortunately, common shocks affecting all member states can be managed by the new central government's monetary authority.

- See Comes and Sandler (1986, chapter 5). 
to be one example of voluntary, but inefficient, provision of an extensive public good. ${ }^{9}$

Central government fiscal policies to complement member states' own fiscal policies also may be needed when labor and capital are freely mobile across state lines, as for example, in the U.S. and the proposed E.E.C.. First, while the free mobility of labor across the members of an economic union will enhance efficiency in pure private goods economies, this conclusion does not necessarily follow in economies with private goods and locally provided public goods. Local public goods benefit all residents (whether citizens or not) but non-residents do not benefit. Examples include clean and safe environments, public health, or educated co-workers.

Recent research on such economies, summarized by the Henry George Theorem, has shown that the efficient financing of such local public goods by the member states requires the full (100\%) taxation of the returns to the immobile resources within the state, for example, taxes on locaily owned land rents or the profits from natural resource activities. Any tax rate less than $100 \%$ implies existing residents share the rents and profits with new residents creating an incentive for workers to locate according to their average, not marginal, products. ${ }^{10}$

If mobile labor imposes a congestion cost on existing residents--for example if the

See Sandler and Murdoch (1990).

10 See Wildasin (1986, sections 2.2 and 2.3) for a full discussion. The case here of pure public goods financed by a $100 \%$ tax on land rents and locationally specific (e.g., natural resource) profits corresponds to Wildasin's case 2 (1986, p. 15). As noted by Boadway and Flatters (1982, p. 621) this locational inefficiency also can be eliminated if all rents and profits are capitalized into land values, and land is required for residency. In this case new residents will not share in local rents and profits. 
local public good is now "impure"--then an additional head tax on new residents equal to their marginal congestion cost imposed on existing residents must be levied. " If, in the limit, marginal congestion costs per resident rise to just equal the average cost per resident of providing the local public good, then a head tax alone will be sufficient to finance the public service. This limiting case corresponds to the famous Tiebout Theorem for the efficient provision of local public goods; in this ideal world, there will be no need for central govemment intervention. ${ }^{12}$

Inefficiencies arise in economies with local public goods when the full taxation of local economic rents and profits and new resident congestion is difficult to implement, either because of informational asymmetries or local distributional politics. Alternatively, local wage taxes, head taxes unrelated to congestion, taxes on mobile capital, or taxes on consumption and exports will typically produce inefficient resource allocations. Often central government fiscal policy can improve resource allocations.

In the case of inefficient taxes on mobile labor, central government grants-in-aid which transfer resources from member states enjoying large shared rents and fiscal

\footnotetext{
${ }^{11}$ This case corresponds to Wildasin's case 5 (1986, p. 17).

${ }^{12}$ See Bewley (1981). In this full congestion case of the Tiebout Theorem, the local head tax not only fully finances local public service provision, but it also serves as an exclusion device for new residents. It is this exclusion property of the local tax which insures preference revelation, and thus guarantees the efficient level of local public goods with mobile residents.

It should be noted that the Henry George Theorem does not include such a preference revelation mechanism; the theorem only guarantees private goods efficiency, given some exogenous level of public goods provision. With full congestion, the Tiebout Theorem shows both private goods and public goods efficiency are possible with a fully decentralized public goods economy.
} 
externalities to less advantaged member states will improve labor allocations in the economy as a whole by encouraging workers to respond to their marginal private products and their marginal public congestion when relocating. ${ }^{13}$

Member state taxation of mobile capital can also be inefficient, and again central government policy intervention can be helpful. Local, or at source, taxation of capital either creates a tax wedge between rates of retums across member states when capital is imperfectly mobile or no revenues at all when capital is perfectly mobile and states compete for capital by lowering rates. The altemative strategy is to tax capital at residence when its earnings are received by savers. Local resident-based capital taxes may be difficult to implement, however. Such taxes require that each state government know each resident's income from capital, even when those capital earnings are from investments outside the state's taxing jurisdiction. Complicated tax treaties among member states will be needed. Further, efforts to manage these tax treaties may create their own inefficiencies, now on the location of financial services. ${ }^{14}$ One appropriate fiscal response is to tax capital at the central govemment level, with proceeds allocated to member states as lump-sum transfers.

Finally, member state taxation of local consumption or sales can be inefficient, particularly when the taxed commodities are exported to residents in other member states. The problem arises when one member state has within its border a locationally-fixed and

\footnotetext{
${ }^{13}$ See Boadway and Flatters (1982).

${ }^{14}$ See Giovannini (1989, pp. 364-366).
} 
economically unique private resource. The favored state can act as an export monopolist by imposing a sales tax on the use of the unique private resource. The analysis extends to two or more exporting member states, if an oligopolistic strategic equilibrium in tax rates is established. ${ }^{15}$ All citizens of the economic union will be potentially better off however when such state taxes on export sales are centrally prohibited. ${ }^{16}$

While the economic case for central government fiscal policies in open public economies is clear, the prospects for their successful implementation are not. How well do such central govemments typically do in achieving the federalist policy agenda outlined here? Again, the recent U.S. experience is instructive.

\section{Fiscal Management by Central Governments: U.S. Evidence}

While the new E.E.C.--and someday, perhaps, a new economic federation of eastern European and Soviet states--has yet to specify the political institutions for deciding union-wide fiscal policies, such institutions are clearly needed. Which political institutions are chosen can have important implications for the efficient management of central govemment fiscal policies. Two classes of democratic institutions should be considered: those which concentrate central government fiscal authority in the hands of a single elected agent (e.g., president or majority party leader) and those which

is See Kolstad and Wolak's (1983) analysis of western U.S. coal producing states where sizeable economic rents were captured through sales taxes by the exporting states.

16 Potential pareto improvements may be all that is possible, since to actually pay compensation to the natural resource rich exporting states may violate conditions for efficient labor mobility. 
decentralize authority among the members of a diffuse legislature (e.g., the U.S. Congress or the European Parliament).

Fiscal policy in the U.S. is currently dominated by a highly decentralized Congress, composed of 435 locally elected Representatives in the House and 100 state elected members of the Senate. In such a legislature, deciding policies by simple majority rule runs the risk of never ending policy cycles: policy $A$ beats $B, B$ beats $C$, but $\mathrm{C}$ beats $\mathrm{A}$. There is an escape from such a cycle, one that appears to be common to many decentralized legislatures including the U.S. Congress. It is called decisionmaking by a "norm of universalism," or more popularly, "pork barrel politics."17 In this environment, fiscal policies are chosen as the (literal) aggregation of locally optimal levels of spending and taxes.

Such "universalistic" legislatures are biased towards an inefficient fiscal policy, however. The problem is closely akin to that which arise with the shared use of a natural resource, only here the shared resource is the central government's current and future tax base. Under a norm of universalism, each legislator selects a locally favored level of central government spending and taxation balancing local benefits and costs. Now, however, local marginal costs are equal to each member state's share of the national tax base (e.g., 1/N, where $\mathrm{N}$ is the number of represented states) multiplied by the true social marginal cost. If central government spending is for goods with differential local benefits, then the tendency is to over-provide central government public

17 The formal logic of this legislative norm was first presented in Weingast (1979), though it has been noted in the history of U.S. legislative decision-making for many years. See Inman and Fitts (1990) for an application of this logic to fiscal policy. 
services. Inman and Fitts (1990) provide some econometric evidence that this has indeed been the case for U.S. fiscal policies in recent years.

The incentives for inefficient spending carry over to the design of central government tax and deficit policies as well. For example, the lack of a clear, and agreed to, definition of capital income raises the possibility that the tax base for central government capital taxation will be decided by the decentralized legislature seeking to maximize local benefits to member states. Such arguably inefficient tax loopholes as oil depletion allowances (Texas, Oklahoma, Louisiana), $\mathrm{R}$ and $\mathrm{D}$ expensing (Silicon Valley), and accelerated depreciation (the growing South) are examples from the U.S. tax code.

Deficits too may be too large when set by inherently unstable decentralized legislatures. Each elected representative will consider the long-run implications of his or her fiscal choices, but only to the limit of his or her own political time horizon. If this horizon is shorter than the societal horizon and legislative decision-making reflects only representative preferences, then there is a bias towards excessive borrowing and lower-than-optimal average tax rates. Roubini and Sachs (1989) found a clear tendency towards larger deficits in OECD countries with decentralized legislatures and more frequent government tumover.

This bias towards inefficient central government fiscal choice can be controlled, but only through alternative political institutions. If the cause of inefficient budgeting are the incentives inherent in decentralized legislatures, then new institutions which centralize fiscal authority in the hands of a democratically elected "agenda-setter" may be required. The two prominent examples of such centralizing institutions are an elected 
executive with budget-setting powers or a majority political party with control over the elected legislature: Inman and Fitts (1990) find evidence in the U.S. historical record that both strong executives and strong parties have significantly reduced central government spending and tax loopholes below that anticipated from a universalistic legislature. The price that the individual member states must pay for this increased efficiency in central govemment fiscal policy is less direct control over their own shares of the central budget.

IV. Conclusion: Striking a Balance

There are important lessons for the nations of the E.C.C. (and eastem Europe too) in the recent economic history of U.S. fiscal federalism. The loss of monetary policy to a central govemment raises the need for a substitute fiscal policy to ease the burdens of state specific economic shocks; centrally provided unemployment insurance has proven to be one workable response. Central government financing and provision of economy-wide public goods--defense, environment, redistribution--will be needed to overcome observed free-rider behavior between member states. When state govemments provide local public goods but use inefficient tax instruments, then countervailing central govemment tax treaties and grants-in-aid may be appropriate. Efforts by the economic union to establish free trade in commodities can be undone by member states which use local sales tax policy to exploit a monopoly position in valued exports. Again, the central government's regulation of member state tax policies may be required. As the U.S. experience makes clear, there is an important role for central governments in the fiscal 
affairs of economic unions.

The recent U.S. experience also emphasizes the difficulties that central governments may have in managing their role in the federalist economy. Decentralized legislatures with tax access to union-wide resources may mismanage those resource by overspending, or under-taxing, for locally favored projects. More centralized political institutions can reduce these fiscal inefficiencies, but only if member states concede control over allocations to an agenda-setting executive or political party.

In the end, each economic union must strike a balance. Protecting the rights of member states to control their own fiscal affairs will typically generate fiscal inefficiencies in federalist economies, either through the direct prohibitions on central government activities or by using decentralized legislatures to manage a more activist agenda. Finding a balance between these competing causes of fiscal inefficiency is central to the design of economic unions.

More important still is to look for new fiscal institutions which might reduce both inefficiencies. Voluntary agreements between member states in decentralized public economies and responsive agenda-setters in centralized public economies are promising alternatives. It is here that the U.S. might hope to learn from the European experience. 


\section{REFERENCES}

Bernard, A. B., and S. N. Durlauf, "Convergence of International Output Measurements, " NBER Working Paper No. 3717, May, 1991.

Bewley, T. F., "A Critique of Tiebout's Theory of Local Public Expenditures," Econometrica, 49 (1981), 713-740.

Boadway, R. and F. Flatters, "Efficiency and Equalization Payments in Federal System of Governments," Canadian Joumal of Economics, 15 (1982), 613-633.

Brown, S. J., N. E. Coulson, and R. F. Engle,"Non-Cointegration and Econometric Evaluation of Models of Regional Shift and Share," NBER Working Paper No. 3291, March, 1990.

Cornes, R. and T. Sandler, The Theory of Externalities, Public Goods, and Club Goods, New York: Cambridge University Press, 1986.

Eichengreen, B., "Currency Unions," Brookings Papers on Economic Activity, (April, 1990), 118-187.

Giovannini, A., "National Tax Systems versus the European Capital Market," Economic Policy, (1989), 346-386.

Gramlich, E. M., "Subnational Fiscal Policy, "Perspectives on Local Public Financeand Public Policy, 3 (1987), 3-27.

Hart, O., "Model of Imperfect Competition with Keynesian Features, " Quarterly Joumal of Economics, 97 (1982), 109-138.

Inman, R. P.and M. A. Fitts, "Political Institutions and Fiscal Policy: Evidence from the U.S. Historical Record, "Joumal of Law, Economics, and Organization, 6 (1990), 79-132.

Kolstad, C. and F. Wolak, Jr., "Competition in Interregional Taxation: The Case of Western Coal," Joumal of Political Economy, 91 (1983), 443-459.

Roubini, N. and J. Sachs, "Political and Economic Determinants of Budget Deficits in the Industrial Democracies," European Economic Review, 33 (1989), 903-938. 
Sandler, T. and J. C. Murdoch, "Nash-Cournot or Lindahl Behavior: An Empirical Test for the NATO Allies," Quarterly Joumal of Economics, 105 (1990), 875-894.

Weingast, B. "A Rational Choice Perspective on Congressional Norms," American Joumal of Political Science, 23, (1979), 245-62.

Wildasin, D., Urban Public Finance, New York: Harwood Academic Publishers, 1986. 